\title{
Can SPECT change the surgical strategy in patients with primary hyperparathyroidism?
}

\author{
O SPECT pode mudar a estratégia cirúrgica nos \\ pacientes com hiperparatireoidismo primário?
}

Letícia lervolino', Nilza Maria Scalisse', Sergio Setsuo Maeda'

\section{SUMÁRIO}

O hiperparatireoidismo primário (HPTP) é a causa mais comum de hipercalcemia diagnosticada ambulatorialmente. É mais frequente no sexo feminino e na pós-menopausa e a prevalência é de 1 a 4:1000 na população geral. 0 adenoma solitário esporádico secretor de PTH corresponde a $90 \%$ dos casos de HPTP, enquanto a doença multiglandular é mais comum nas síndromes de hiperparatireoidismo familiar (5\%) e o carcinoma de paratireoide representa menos de $1 \%$ dos casos. Somente após a certeza da autonomia funcional de uma ou mais glândulas paratireoides é que devem ser realizados exames de imagem localizatórios, com a finalidade de planejar o procedimento cirúrgico. Além disso, esses exames apresentam limitações e podem resultar em falsos-positivos e negativos. Há casos em que a localização da glândula paratireoide é de extrema dificuldade, sendo necessária a associação de métodos de imagem para localização pré-operatória como o uso do ${ }^{99 \mathrm{mT}} \mathrm{Tc}$-pertecnetato, SPECT, SPECT/CT e a ultrassonografia. Descrevemos um caso de paciente feminina, 50 anos, com diagnóstico de hiperparatireoidismo primário, submetida a um procedimento cirúrgico sem sucesso, com manutenção da hipercalcemia e do hiperparatireoidismo, em que, somente após a realização da cintilografia associada ao SPECT/ CT, foi possível localizar a glândula paratireoide hiperfuncionante em região retrotraqueal. Arq Bras Endocrinol Metab. 2012;56(4):265-9

\section{SUMMARY}

Primary hyperparathyroidism (PHPT) is the most common cause of hypercalcemia in outpatients. It is more common in females, after menopause, and the prevalence is 1 to 4:1000 in the general population. Patients with PHPT have abnormal regulation of PTH secretion, resulting in elevated serum calcium and inappropriately high or normal PTH in relation to the calcium value. Sporadic PTH-secreting adenoma alone accounts for $90 \%$ of cases of PHPT, while multiglandular hyperplasia is more common in familial hyperparathyroidism syndromes $(5 \%)$ and parathyroid carcinomas represent less than $1 \%$ of cases. Only after making sure there is functional autonomy of one or more parathyroid glands, localization imaging tests should be performed to guide a possible surgical procedure. It is important to highlight that these tests have limitations and can yield false-positive and false-negative results. There are cases in which the parathyroid gland is difficult to be located, requiring a combination of imaging methods for pre-operative localization, such as ${ }^{99 m}$ Tc-pertechnetate, SPECT, SPECT/CT, and US. We describe the case of a 50-year-old female patient diagnosed with PHPT, who underwent a surgical procedure without success, with maintenance of hypercalcemia and hyperparathyroidism. In this case, the hyperfunctioning parathyroid was located in the retrotracheal region only after scintigraphy combined with SPECT/CT were used. Arq Bras Endocrinol Metab. 2012;56(4):265-9
1 Discipline of Endocrinology, Department of Medicine, Faculdade de Medicina da Santa Casa de São Paulo (FMSCSP), São Paulo, SP, Brazil
Correspondence to: Letícia lervolino Av. Angélica, 696, ap. 61 01228-000 - São Paulo, SP, Brazil leiervolino@hotmail.com

Received on Feb/5/2012 Accepted on May/23/2012 


\section{INTRODUCTION}

$\mathrm{P}$ rimary hyperparathyroidism (PHPT) is the most common cause of hypercalcemia in outpatients $(1,2)$. It is more common in females, especially postmenopausal ones (3), and the prevalence is 1 to 4:1000 in the general population (1).

PHPT is characterized by abnormal regulation of PTH secretion, leading to elevated serum calcium and normal or inappropriately high levels of PTH in relation to the corresponding calcium values. Sporadic PTH-secreting adenoma accounts for $90 \%$ of the cases, whereas multiglandular disease is more common in familial syndromes $(5 \%)$, and parathyroid carcinomas represent less than $1 \%$ of the cases (3).

Only after making sure that one or more parathyroid glands have functional autonomy, imaging studies should be performed to locate it and facilitate the surgical approach. It is important to highlight that these tests have limitations and can result in false-positives and false-negatives (2).

Scintigraphy with ${ }^{99 \mathrm{~m}} \mathrm{Tc}$-Sestamibi is the gold standard method for localization, but most of the services perform only planar images (two dimensions). The association with SPECT (Single Photon Emission Computed Tomography) or SPECT/CT allows more accurate three-dimensional anatomical localization of abnormal areas in scintigraphy. The advantage of this association is that it combines assessment of glandular function with anatomic location, significantly contributing to surgical planning, especially when cervical anatomy is distorted, in cases of prior cervical surgery and ectopic adenomas (4).

The presence of an ectopic hyperfunctioning parathyroid gland or multiglandular hyperplasia is the main cause of persistent and recurrent hyperparathyroidism. The inferior parathyroid glands are derived from the epithelium of the dorsal bulbar part of the third pharyngeal pouches, and the superior parathyroid glands, from the dorsal part of the fourth pouches. Parathyroid glands are usually located posteriorly to the thyroid, but their location may vary. The position of the superior glands is more constant than that of the inferior ones. They can be found anywhere near or within the thyroid or thymus. Occasionally, the inferior parathyroids may be close to the bifurcation of the common carotid artery, and in other cases, they may follow the thymus into the chest, considering to be ectopic parathyroids (5).

\section{CASE REPORT}

This case report was previously approved by the Ethics Committee of Faculdade de Medicina da Santa Casa de São Paulo, and the patient signed an informed consent form. A female patient, MLPG, 50 years old, who was born and raised in São Paulo, and presented mental retardation of unknown etiology, underwent total thyroidectomy for multinodular goiter in the past.

In 2008, she was diagnosed with osteoporosis in a bone densitometry scan. During the investigation, hypercalcemia and high PTH were found (Table 1). Parathyroid scintigraphy ( ${ }^{99 \mathrm{~m}} \mathrm{Tc}$-Sestamibi) showed a high uptake area near the sternal notch to the right, which may have corresponded to the lower right hyperfunctioning parathyroid (Figure 1). The patient underwent parathyroidectomy (pathology study: thymus fragments with diffuse lymphoid hyperplasia and areas of distorted architecture). However, after the first procedure, the laboratory profile was not resolved (Table 1).

In March 2010, continuing the investigation, cervical MRI detected a $0.7 \mathrm{~cm}$ nodular image in the left paratracheal region with mild contrast uptake. It was not possible to differentiate between a lymphonode and an increased parathyroid. Due to the unsuccessful previous surgical treatment, a ${ }^{99 \mathrm{~m}} \mathrm{Tc}$-sestamibi scintigraphy complemented with SPECT/CT was performed, and a right retrotracheal parathyroid adenoma was detected (Figure 2). The patient underwent another surgery (pathology study: parathyroid adenoma) in July 2010. The parathyroid adenoma was localized with a significant drop in intraoperative PTH (IO-PTH time $0=299 \mathrm{pg} / \mathrm{mL}$, IO-PTH 15 minutes after parathyroidectomy $=21 \mathrm{pg} / \mathrm{mL}$ ).

Currently, the patient evolved to normocalcemia and, six months after surgery, bone densitometry showed improvement in bone mass with a $12 \%$ increase in bone mineral density in the femoral neck, a $36 \%$ increase in total femur, and a $4 \%$ increase in the lumbar spine after 6 months of the second surgery (Table 1).

Table 1. Pre- and post-operative laboratory exams

\begin{tabular}{lccc}
\hline Exams & Basal & $\begin{array}{c}\text { After 1st } \\
\text { surgery }\end{array}$ & $\begin{array}{c}\text { After 2nd } \\
\text { surgery }\end{array}$ \\
\hline Total calcium (mg/dL, RV: 8.8-10.3) & 10.8 & 11.2 & 9.3 \\
PTH (pg/mL, RV: 12-65) & 318 & 208 & 58 \\
Bone densitometry (T-score) & & & \\
L1L4 & -1.35 & & -1.0 \\
Femoral neck & -2.65 & - & -2.1 \\
Total femur & -2.68 & & -2.6 \\
\hline
\end{tabular}




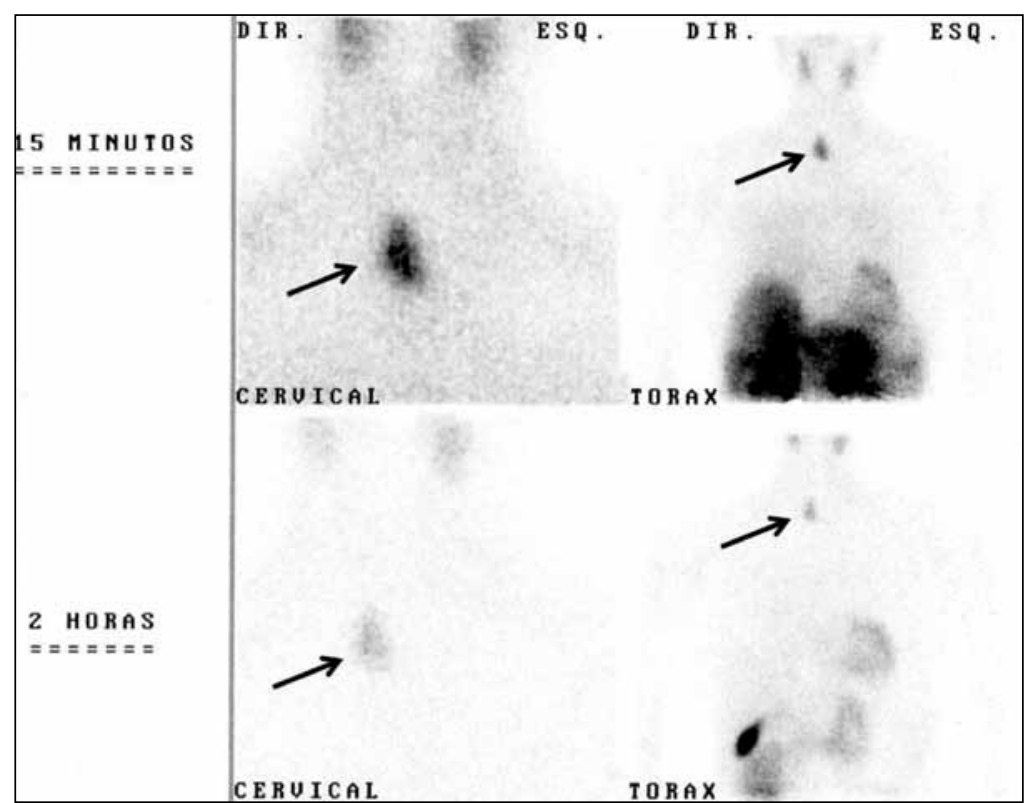

Figure 1. Parathyroid scintigraphy ( ${ }^{99 m} \mathrm{Tc}$-Sestamibi) showing an area of high uptake near the sternal notch, to the right.

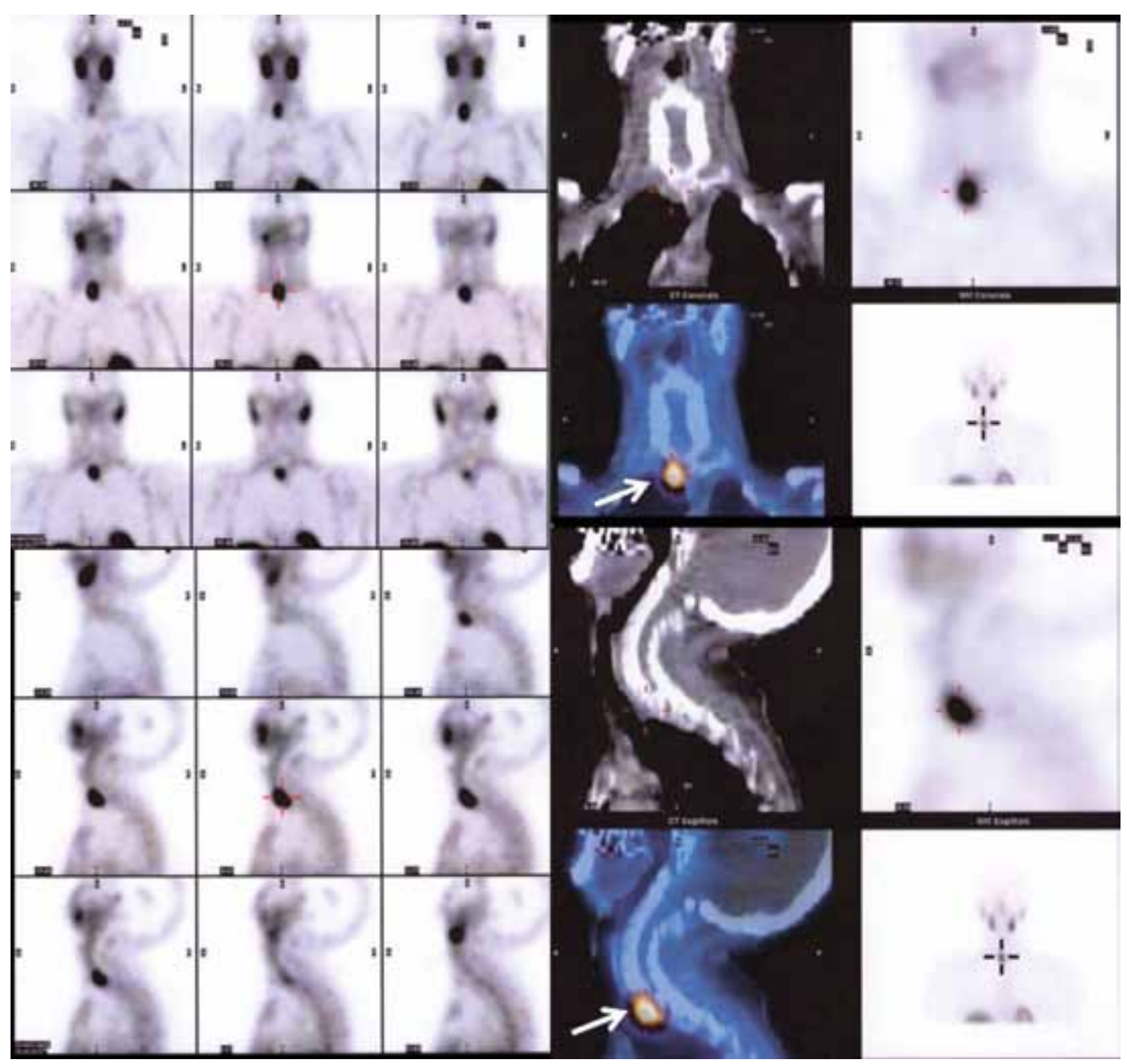

Figure 2. ${ }^{99 m}$ TC-Sestamibi scintigraphy complemented with SPECT/CT. 


\section{DISCUSSION}

We described the case of a patient who, after undergoing a surgical procedure without success, progressed with persistent hypercalcemia and elevated PTH. The second preoperative localization of hyperfunctioning parathyroid adenoma was possible with scintigraphy with SPECT/CT, which featured an ectopic gland in the retrotracheal region. After new surgical procedure, with excision of the adenoma, the clinical picture was improved.

Multiple methods for localizing parathyroid glands can be used, such as scintigraphy, ultrasonography, computed tomography, and magnetic resonance imaging. Scintigraphy in two phases (15 and 120 minutes) is performed with ${ }^{99 \mathrm{~m} T c-S e s t a m i b i}$. The high uptake in hyperfunctioning parathyroid is explained by that in this cells there is a large number of abnormal mitochondria for which Sestamibi has high affinity, since the washout of the thyroid is faster $(6,7)$. In most services, only two-dimensional planar images are made, which caused the first scintigraphy in this case to be misinterpreted.

Although planar images of the parathyroid have a relatively high accuracy, intra-thyroid adenomas with low ${ }^{99} \mathrm{~m} \mathrm{Tc}$-sestamibi uptake and ectopic adenomas may be neglected. The use of double tracer ${ }^{99}{ }^{9} \mathrm{Tc}-S e s t a m i-$ bi and ${ }^{99} \mathrm{Tc}$-pertechnetate) associated with SPECT and computed tomography allow the localization of the parathyroid adenoma in three dimensions, the differentiation from thyroid lesions (only the thyroid can uptake

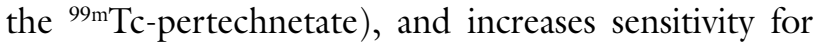
the detection of the affected gland in $90 \%$, aiding in surgical planning (8).

However, the routine use of SPECT before surgery is still controversial. According to Lorberboym and cols. (9), combined planar scintigraphy identified 79\% of the adenomas and the use of SPECT increased sensitivity to $96 \%$, with SPECT being superior to the planar image in $17 \%$ of the cases, mainly in patients with ectopic parathyroid or multiglandular goiter. Another study evaluated the detection of parathyroid adenomas smaller than $1 \mathrm{~g}$ in 92 patients with PHPT. The correct localization of the adenoma using planar images was $87 \%$ while with the association of SPECT, the sensitivity increased to $95 \%$, allowing us to conclude that SPECT can improve the investigation efficiency (10).

On the other hand, some authors believe that SPECT does not bring additional information, not improving the detection rate for adenomas. Chen and cols. (11) concluded that the latter images, subtraction images and SPECT are not necessary, given they bring little information other than early images with ${ }^{99} \mathrm{Tc}$ -pertechnetate. Staudenherz and cols. (12) evaluated patients with thyroid disease ( $50 \%$ of the cases) and previous cervical surgery ( $21 \%$ of the cases) submitted to planar images with ${ }^{99 \mathrm{~m} T c-M I B I}$, SPECT, US, and subtraction scintigraphy with ${ }^{201} \mathrm{Ta}$ and ${ }^{99} \mathrm{Tc}$-pertechnetate. The images were then compared with the histopathology of the surgical specimen. The analysis showed that the use of SPECT provided additional information for tumor localization in $39 \%$ of the patients with thyroid disease or previous cervical surgery, but did not increase overall detection rates, suggesting that this exam should not be used for all patients with PHPT.

Recent advances in the techniques of pre-operative localization of parathyroid adenomas allow better planning and surgical success. The combination of ultrasonography and scintigraphy is the most appropriate approach, and the ideal situation is to find a good correlation between these methods. The cases of ectopic adenomas and adenomas located deep in the cervical region are rare, accounting for 3\%-6\% of cases. However, they are a challenge for the surgeon and a frequent cause of failure if accurate localization tests are not performed before the procedure. In these patients, it is useful to perform SPECT or SPECT/CT after conventional scintigraphy, because this approach provides useful information for the surgeon (13).

It is important to highlight that conventional parathyroid scintigraphy can result in false-positive and false-negative results. The most common cause of false-positive results is the solitary and solid thyroid nodule or the multiglandular goiter. Benign or malignant tumors can capture the radiotracer and may result in false-positives, including thymoma, breast, lung, head and neck cancer, as well as their metastases to bone and lymphonodes, and bronchial carcinoid tumors (8).

The most common factor associated with false-negative findings is the size of the parathyroid gland, the smaller ones being more difficult to detect (currently $80 \%$ of adenomas are very small, weighing less than l g) (14). The false-negative cases may occur in patients with multiglandular parathyroid disease (multiple endocrine neoplasia and chronic renal failure). The variability in radiotracer uptake in adenomas is another factor that may affect its localization and is associated with differences in perfusion and metabolic activity; the amount of oxyphilic cells; the expression of P-glycopro- 
tein, and the multi-drug resistance related to protein expression and celular cycle (8).

The adoption of techniques that combine images with ${ }^{99 m}$ Tc-pertechnetate, SPECT scintigraphy and conventional computed tomography $\left({ }^{99 \mathrm{~m}} \mathrm{Tc}-\mathrm{Sestamibi}\right)$, increase sensitivity, provide useful topographical information for the differentiation between parathyroid and thyroid tissue, and may help to decrease the percentage of unsuccessful surgeries due to ectopic adenomas not found intra-operatively (7). Finally, the use of IO-PTH can help detecting the surgical cure or the need to keep surgical exploration when there is no decrease in the tracer.

Disclosure: no potential conflict of interest relevant to this article was reported.

\section{REFERENCES}

1. Taniegra ED. Hyperparathyroidism. Am Fam Physician. 2004;69(2):333-9.

2. Khan A, Bilezikian J. Primary hyperparathyroidism: pathophysiology and impact on bone. CMAJ. 2000;163(2):184-7.

3. Ferris RL, Simental AA Jr. Molecular biology of primary hyperparathyroidism. Otolaryngol Clin North Am. 2004;37(4):819-31.

4. Radan L, Gorenberg M. The value of SPECT/CT $99 \mathrm{mTC}$-sestamibi scintigraphy in the diagnosis of ectopic parathyroid adenoma. Isr Med Assoc J. 2009;11(7):448.

5. Moore KL, PersaudTVN. Embriologia clínica. $7^{\mathrm{a}}$ ed. Rio de Janeiro: Elsevier; 2004.

6. Ng P, Lenzo NP, McCarthy MC, Thompson I, Leedman PJ. Ectopic parathyroid adenoma localized with sestamibi SPECT and image-fused computed tomography. Med J Aust. 2003;179(9):485-7.

7. Oliveira MA, Maeda SS, Dreyer P, Lobo A, Andrade VP, Hoff AO, et al. Importância da complementação com SPECT e 99mTc na cintilografia das paratireóides e da correlação clínica, laboratorial, ultrassonográfica e citológica na localização pré-operatória do adenoma de paratireoide - ensaio pictórico. Arq Bras Endocrinol Metabol. 2010;54(4):352-61.

8. Eslamy HK, Ziessman HA. Parathyroid scintigraphy in patients with primary hyperparathyroidism: $99 \mathrm{mTc}$ sestamibi SPECT and SPECT/CT. Radiographics. 2008;28(5):1461-76.

9. Lorberboym M, Minski I, Macadziob S, Nikolov G, Schachter P. Incremental diagnostic value of preoperative $99 \mathrm{mTc}-\mathrm{MIBI}$ SPECT in patients with a parathyroid adenoma. J Nucl Med. 2003;44(6):904-8.

10. Moka D, Voth E, Dietlein M, Larena-Avellaneda A, Schicha H.Technetium 99m-MIBI-SPECT: a highly sensitive diagnostic tool for localization of parathyroid adenomas. Surgery. 2000;128(1):29-35.

11. Chen CC, Holder LE, ScovillWA, Tehan AM, Gann DS. Comparison of parathyroid imaging with technetium-99m-pertechnetate/sestamibi subtraction, double-phase technetium-99m-sestamibi and technetium-99m-sestamibi SPECT. J Nucl Med. 1997;38(6):834-9.

12. Staudenherz A, Abela C, Niederle B, Steiner E, Helbich T, Puig S, et al. Comparison and histopathological correlation of three parathyroid imaging methods in a population with a high prevalence of concomitant thyroid diseases. Eur J Nucl Med. 1997;24(2):143-9.

13. Rubello D, Casara D, Pagetta C, Piotto A, Pelizzo MR, Shapiro B. Determinant role of Tc-99m MIBI SPECT in the localization of a retrotracheal parathyroid adenoma successfully treated by radioguided surgery. Clin Nucl Med. 2002;27(10):711-5.

14. Uludag M, Isgor A, Yetkin G, Atay M, Kebudi A, Akgun I. Supernumerary ectopic parathyroid glands. Persistent hyperparathyroidism due to mediastinal parathyroid adenoma localized by preoperative single photon emission computed tomography and intraoperative gamma probe application. Hormones (Athens). 2009;8(2):144-9. 